http://dx.doi.org/10.12775/szhf.2019.026

\title{
François Noudelmann, Geniusz kłamstwa, przeł. Magdalena Łachacz i Michał Krzykawski, PWN, Warszawa 2018, ss. 428
}

Podobno niemiecki filozof Max Scheler, uchodzący za rygorystę w sferze moralności, miał być niegdyś przyłapany przez swoich studentów na tym, jak wychodził z domu publicznego. Cały zaś incydent miał skomentować w taki oto sposób: „Drogowskaz jest po to, by drogę wskazywać, a nie by po niej chodzić". Niezależnie od tego, czy przywoływana anegdota jest prawdziwa i czy twórca fenomenologicznej teorii wartości faktycznie był bywalcem domu schadzek - trzeba przyznać, że rysujący się tu problem nie jest bez znaczenia dla refleksji etycznej: czy można być drogowskazem, nie postawiwszy choćby na moment stopy na szlaku, który się wskazuje? Czy filozofia jako dyskurs i filozofia jako styl życia to dwa nieprzystające do siebie elementy ludzkiej praxis, które można realizować w sposób ze sobą sprzeczny i jednocześnie móc ze spokojnym sumieniem mienić się filozofem?

Ideał, który promowała antyczna filozofia, zakładał, że nauka ta jest niczym innym jak sztuką życia: filozof głoszący poglądy przeciwne swojemu modus vivendi nie mógł liczyć na to, że zgromadzi wokół siebie wielu uczniów. Najlepszym tego obrazem są Żywoty i poglądy stynnych filozofów Diogenesa Laertiosa - nawet jeśli nieco ubarwione kronikarską fantazją, są swoistym zbiorem biografii, na podstawie których trudno jest oddzielić poglądy od zachowań ich twórców i propagatorów. Opublikowana niedawno nakładem PWN książka Geniusz kłamstwa zadaje kłam takiej nader spójnej i pozbawionej rys relacji, która łączy miłośników mądrości z ich przekonaniami. 
Jej autor, François Noudelmann, profesor związany z Wydziałem Literatury Francuskiej i Frankofońskiej w Université Paris-VIII, stawia nieoryginalną, acz odważną tezę o tym, że filozofów i moralistów, zwłaszcza tych o skrajnie rezonerskich inklinacjach, nierzadko cechuje wprost proporcjonalna do nich hipokryzja i przewrotność.

Teza ta, powtórzę raz jeszcze, jest dość nieoryginalna, gdyż choćby nawet u wspomnianego Laertiosa można się natknąć na niezbyt pokrzepiające obrazy filozofów, których z propagowanymi ideami łączy jedynie to, że są ich autorami. Pracę tę na tle innych, typowo biograficznych, wyróżnia to, że jej twórca nie ogranicza się do tropienia wszelkiego rodzaju rozdźwięku między - by posłużyć się terminami z języka psychoanalizy - id, ego a superego filozofów i tego, jak radzą oni sobie z powstającym wskutek niego dysonansem poznawczym, aby potem $\mathrm{z}$ iście cyniczną przyjemnością powiadomić czytelników o wynikach swoich demaskatorskich badań, lecz idzie o krok dalej. Publikacja Geniusz kłamstwa, którą gatunkowo należałoby zaliczyć do eseju filozoficzno-literackiego, to raczej niewielkie studium kłamstwa traktujące o tym, jak „nieczyste sumienie może być motorem napędowym nie tylko moralności, ale również teorii” (s. 184).

Trzeba w tym miejscu przyznać, że uznanie reakcji indywidualnej moralności na skutki jej uwikłania w czyny moralnie naganne za akt fundujący całą moralność jest tezą jeszcze bardziej wywrotową od tezy wyjściowej. Gdy jednak przyjrzymy się żywotom i poglądom poszczególnych filozofów, potraktowanych przez autora mimo wszystko z dużą dozą życzliwości, okazuje się, że nawet jeśli globalnie teza zostałaby obalona, w tych konkretnych przypadkach rozpatrywanych jako exempla osób o konkretnych predyspozycjach psychicznych i moralnych, trudno odmówić Noudelmannowi racji.

Zanim jednak autor przystąpi do obnażania „werbalnej hipertrofii” myślicieli górującej nad ich rzeczywistym postępowaniem (skupia się głównie na bliższych mu kulturowo i naukowo sylwetkach filozofów francuskich), pochyla się nad tytułowym „geniuszem kłamstwa”. Decyduje się przyjąć podejście amoralne, gdyż w jego mniemaniu: „moralne potępianie kłamstwa uniemożliwia ocenę jego złożoności” (s. 9). A to właśnie o zbadanie skomplikowanego charakteru ludzkiej zdolności do mówienia i poświadczania nieprawdy chodzi Noudelmannowi: w swojej amoralnej analizie kłamstwa 
odchodzi od pojęcia intencji, postrzegając kłamstwo nie jako świadomy i intencjonalny akt (wszak można oszukiwać samego siebie, nawet o tym nie wiedząc), i skupia się na konstruowanej przez podmiot rzeczywistości.

Noudelmanna, podobnie jak „mistrzów podejrzliwości” - Friedricha Nietzschego i Zygmunta Freuda, do których zresztą nawiązuje, fascynuje kreatywny potencjał kłamstwa: konfabulacje, podejrzane dopełnianie prawdy ozdobnikami, przeinaczenia i powtórzenia, tworzenie wielopiętrowych konstrukcji myślowych. Francuskiego filozofa interesuje zwłaszcza notoryczna rekurencyjność, tj. niemal obsesyjne powtarzanie danej kwestii, co mogłoby - z freudowskiej perspektywy - wskazywać na pewien dysonans między wypowiedzią a jej realnym znaczeniem, między „ja” realnym a ,ja” idealnym czy ,ja” powinnościowym.

Filozofowie są tu na uprzywilejowanej pozycji - wszak nad wyraz łatwo schować wszystkie wewnętrzne konflikty pod płaszczykiem abstrakcyjnego języka, który nie wiadomo co denotuje w postmodernistycznym świecie słownych gier. Jeśli stwierdzenie to odczytać w świetle słów Nietzschego z Poza dobrem i złem: „wyjaśniło mi się z wolna, czem była dotychczas każda wielka filozofia: oto spowiedzią swego twórcy", to może się okazać, że wiele $\mathrm{z}$ tych filozoficznych spowiedzi było świętokradzkich.

Noudelmann jednak przestrzega przed nazbyt szybką utratą zaufania pokładanego w filozofach jako „wieszczach prawdy” - przeważnie są to kłamcy nieintencjonalni: ich poglądy wyrastają niejako na przekór przeżywanemu życiu. Nietzsche tłumaczył ten rozdźwięk resentymentem, Freud - niezażegnaną traumą, wymykającą się introspekcji. Noudelmann nazywa nieintencjonalne kłamstwa myślicieli, żyjących w sposób daleki od głoszonych idei, „przeinaczającym wymysłem językowym, który wyraża pewna prawde $w$ formie kłamstwa" (s. 22). Jak zatem jego zdaniem rozwija się filozoficzny dyskurs myślicieli-drogowskazów niepodążających wskazywaną przez siebie ścieżką?

„Dyskurs - kontynuuje Noudelmann - nie rozwija się «pomimo» przeciwnego zachowania ani «wbrew» niemu, tylko wytwarza się "począwszy od niego»! Należy więc odwrócić formułę: «Ów myśliciel głosi taką zasadę, chociaż zachowuje się inaczej» i nad nią przekładać inną: «Ów myśliciel głosi taką zasadę, ponieważ żyje odwrotnie do tego, co teoretyzuje»" (s. 22). Przewartościowanie zostało, jak widać, doprowadzone przez No- 
udelmanna do ekstremum. Zamiarem francuskiego naukowca jest zatem rekonstrukcja i analiza poglądów najznamienitszych myślicieli w historii filozofii z zamierzonym dystansem, $\mathrm{z}$ odrzuceniem naiwnego $\mathrm{w}$ jego mniemaniu przekonania o identyczności filozofia z jego poglądami. Z rozważań tych przeziera także inne pytanie, może jeszcze bardziej frapujące: „Kim jesteśmy, kiedy myślimy? Jesteśmy wówczas sobą czy kimś innym?” (s. 24). Bo skoro jedność podmiotu nie wspiera się na transparentnej relacji między tym, co podmiot głosi, a tym, co realizuje, może rzeczywiście sama idea „ja” to fikcja, „chaos atomów” - i nic ponadto?

W pięciu rozdziałach książki Noudelmann postanawia zbliżyć się do odpowiedzi na to pytanie. Rozdział pierwszy, Patos prawdy, poświęcony jest na przekór tytułowi całej monografii, prawdzie, a mówiąc ściślej: niemal kompulsywnemu przymusowi, któremu ulegają miłośnicy mądrości, do uznawania się za jej świadków, piewców i niestrudzonych apologetów w myśl przytoczonego przez Noudelmanna dictum przypisywanego Juwenalisowi: Vitam impendere vero („Życie poświęcić prawdzie”). Oprócz wyłożonej tu teorii kłamstwa (według Michela de Montaigne’a, Jean-Jacques'a Rousseau, Immanuela Kanta, Benjamina Constanta i Friedricha Nietzschego) francuski filozof dokonuje pierwszych „demaskacji”. Najpierw obnaża hipokryzję wspomnianego Rousseau, który w Wyznaniach wielokrotnie podkreśla swój niemal miłosny stosunek do prawdy, a w Emilu, traktacie o wychowaniu, przedstawia się z kolei jako pedagog doskonale świadom jasnych i ciemnych stron ludzkiej natury. Natury, nad którą sam wydaje się nie panować, czemu daje wyraz, pozostawiając piątkę dzieci w przytułkach i będąc utrzymankiem mrowia kochanek.

Rozdział drugi pt. Teoria jako przeciwieństwo życia, kontynuujący refleksję o Rousseau, wyznacza oś całej książki. Noudelmann próbuje wykorzystać rozważania Pierre’a Hadota, cenionego specjalisty w zakresie filozofii starożytnej, na temat jedności filozofii jako dyskursu oraz filozofii jako pewnej egzystencjalnej praktyki do własnych celów. Autor Geniusza kłamstwa, powołując się na autorytet Hadota, zdaje się krytykować postmodernistyczną „śmierć autora”, która jako postulat eliminuje w badaniach nie tylko nad literaturą, ale także nad historią filozofii ważny element, jakim są intencje autorskie. Następuje tu także druga „demaskacja”: Jean-Paula Sartre’a, który z pewnych powodów żarliwie głosi idee zaangażowania i złej 
woli, także w kontekście politycznym, samemu przyłączając się jednak do ruchu oporu w ostatnich miesiącach okupacji niemieckiej.

Rozdział trzeci zatytułowany Fetyszyzm pojęcia traktuje o często przecenianej roli filozofii - nie tylko teoretyzującej i spekulującej, ale także tworzącej pewien symboliczny język. Noudelmann wychodzi z założenia, że język filozofów tworzy nowe pojęcia, a starym, często potocznym, słowom nadaje nowe znaczenia, jak również - pozostając koniec końców wytworem subiektywnej psychiki - szczególnego rodzaju relację między tymi pojęciami a swoim twórcą. A co jeśli filozoficzne konstrukcje (a przynajmniej niektóre) są freudowskimi fetyszami, w których jak w lustrze odbija się psychika ich autora - wraz z jej nie do końca czystymi intencjami? Czasem, o czym także rozprawia Noudelmann na przykładzie Gillesa Deleuze’a, pojęcia mogą być narzędziami służącymi do autokreacji własnej podmiotowości. A właściwie próbą przeskoczenia własnych ograniczeń, co Nuodelmann usiłuje wykazać, kontrastując tworzoną przez Deleuze’a filozofię nomadyzmu z jego domatorstwem i awersją do podróży.

Rozdział czwarty, Osobowości mnogie, jest próbą poddania filozoficznej analizie dynamiki życia wewnętrznego filozofów i literatów jako osób, w mniemaniu Noudelmanna, szczególnie podatnych na wszelkiego rodzaju aberracje tożsamości, które można streścić sformułowaniem: „żyć w sprzeczności z tym, co się pisze, lub pisać w sprzeczności z tym, jak się żyje" (s. 285). Podatność ta może wiązać się z tym, że osoby zanurzone czy to w literackiej fikcji, czy rzeczywistości filozoficznej abstrakcji żyją niejako „podwójnie” - w świecie „tu”, codziennej egzystencji, i jednocześnie w świecie „tam”, czyli idei, które tworzą albo z którymi obcują. Rozpostarcie to może przybrać formę, co sugeruje Noudelmann, poznawczego dysonansu: gdzie znowuż „ja” idealne, które przeziera z tworzonego przez filozofa dyskursu teoretycznego, nie zbiega się w żaden sposób z „ja” realnym, o którym donoszą jego biografowie. Albo z ,ja”, które relacjonuje on sam - jak przywoływana w rozdziale Simone de Beauvoir, z równą gorliwością oddająca się pracy nad Druga płcią oraz twórczością autobiograficzną. Jeśli dodać jeszcze do tego pośmiertną publikację korespondencji z jej kochankiem, amerykańskim pisarzem Nelsonem Algrenem, w rezultacie otrzyma się kilka skonfliktowanych ze sobą tożsamości (przy założeniu Noudelmanna, że model teoretyczny Drugiej płci rzeczywiście był 
projekcją ,ja” idealnego filozofki), z których nadrzędny okazuje się dylemat wyboru między niezależnością kobiety kładącej podwaliny feminizmu a jej uległym alter ego tęskniącym za miłosnym, niemal mistycznym, połączeniem z Algrenem.

Czasem filozofowie - i to ostatni temat rozdziału - niejako sami zdejmują z siebie jarzmo wewnętrznych sprzeczności, podporządkowując myśli i idee określonym fikcyjnym osobowościom sygnowanym różnymi pseudonimami. Tu uwaga Noudelmanna przenosi się na przypadek Sørena Kierkegaarda, duńskiego filozofa, ukrywającego się w swych dziełach pod heteronimami. Być może właśnie ten zabieg uchronił go przez rozpadem jego ego w obliczu głoszonych przez niego sprzeczności - wszak jak inaczej wytłumaczyć pochwałę małżeństwa jako wyrazu najwyższej miłości wypływającą z ust mężczyzny przez całe życie unikającego towarzystwa kobiet i umierającego bezżennie?

Esej Geniusz kłamstwa Noudelmann usiłuje domknąć ogólną refleksją na temat kłamstwa zgodnie z przyjętą przez siebie amoralną i nieosądzającą perspektywą. Próba wyjaśniania kłamstwa bez odniesień do takich pojęć jak „intencja” czy „wola” z konieczności musi zmienić się jednak w rozważania o bardziej psychologicznym charakterze. Nie jest to zarzut, gdyż autor już na początku deklaruje, że rezygnuje z jakichkolwiek nawiązań do etyki. Aczkolwiek ich brak pozbawia książkę Noudelmanna jakiejś głębi. $\mathrm{W}$ gruncie rzeczy ostatni rozdział powiela bowiem to, co zostało powiedziane do tej pory: nie każda filozofia narodziła się z kłamstwa, ale żywoty wielu myślicieli pokazują, że niemała część idei powstała w klimacie zaprzeczeń, racjonalizacji, wyparcia i kompromisów z prawdą. Szkoda, gdyż $\mathrm{w}$ wyniku tego uproszczenia postulat francuskiego filozofia, by przyjrzeć się poszczególnym poglądom myślicieli w sposób mniej akademicki, a bardziej biograficzny, nie doczekał się konkluzywnej refleksji, która spoiłaby poprzednie, skądinąd interesująco napisane rozdziały.

Niemniej jednak jeśli potraktować esej Françoisa Noudelmanna nie jako wnikliwe studium nad kłamstwem, ale jako ciekawą monografię na temat relacji, jakie łączyły znanych myślicieli z opracowanymi przez nich koncepcjami, to książka całościowo wypadnie pozytywnie. Autor sprawia wrażenie, że zgłębił te relacje bardzo dobrze (już we wstępie przyznaje, że dobór filozofów nie był przypadkowy - są to autorzy szczególnie mu bli- 
scy), ze swobodą porusza się w tekstach źródłowych i literaturze przedmiotu. Literacki i kwiecisty styl oraz język autora, mimo iż czasem nazbyt pretensjonalne, są dodatkową wartością książki. Krótko mówiąc, Geniusz kłamstwa, choć „niegenialny” - wart jest polecenia.

Dawid Wincław Uniwersytet Mikołaja Kopernika, Toruń, Polska ORCID: 0000-0002-0738-4057 e-mail: dwinclaw@doktorant.umk.pl 